\title{
O HUMILDE SUBLIME EM VITORINO NEMÉSIO
}

\author{
Denílson Luís dos Santos Moreira ${ }^{1}$
}

RESUMO: Com extrema habilidade de justapor o erudito e o popular, Vitorino Nemésio, na linhagem de António Nobre, desenvolveu em versos a arte de criar um humilde que é sublime ou vice-versa. Pretendemos, portanto, identificar os casos em que o autor de Sapateia açoriana expressa, como matéria poética, sua especial compaixão à gente humilde.

PALAVRAS-CHAVE: Humilde; sublime; Nemésio; erudito; popular.

\begin{abstract}
With extreme skill of joining what is erudite and popular, Vitorino Nemésio, in Antônio Nobre's stirp, has developed in verses the art of creating an humble that is sublime or vice versa. We intend, however, to identify cases which Sapateia açoriana's author expresses, as a poetry subject, his special compassion to the humble people.
\end{abstract}

KEYWORDS: Humble; sublime; Nemésio; erudite; popular.

\footnotetext{
${ }^{1}$ Mestrando em Literatura Portuguesa pela USP (Universidade de São Paulo).
} 
"Quem canta, seu mal espanta." Assim começa Nemésio em "O Cancioneiro Popular", escrito em 10 de novembro de 1943 e que é um dos textos de crítica que constituem Conhecimento de Poesia. Para este poeta açoriano, a cantiga quadrada, simples e estrita como uma dentada de pão, engana o mal de viver. Lá diz ela: "Quando vou pra minha casa,/ E a mulher não tem pra ceia,/ Pego na minha viola:/ Já minha casa está cheia". (NEMÉSIO, 1997, 53). Ainda nesse texto crítico, destacamos do autor de Sapateia Açoriana o seguinte pensamento sobre o melhor da cantiga popular: “(...) é esse sentimento do desabafo, espécie de água que deita por fora do cântaro português levado à fonte" (IDEM, 1997, 54). Por isso, mais à frente, ele diz: "Mas quem é povo canta, até na guerra e talvez às portas da morte".

Diante desses e de muitos outros motivos levantados em seu texto de crítica, Nemésio sentencia: "Como vêem, a poesia popular é uma coisa muito séria. Todos os poetas que quiseram ouvir as fontes verdadeiras do nosso sentir português e brasileiro pegaram na cantarilha da quadra e lá foram enchê-la" (IDEM, 1997, 57).

Para o escritor de Mau tempo no canal, o cotidiano, as tradições, as agruras, a religiosidade, a vida, enfim, do povo foi-lhe um tema muito caro. Com extrema habilidade de justapor o erudito e o popular, Nemésio, na linhagem de António Nobre, desenvolveu em versos a arte de criar um humilde que é sublime e vice-versa. Pretende, portanto, nas próximas linhas identificar os momentos em que o autor de Poemas Brasileiros expressa, como matéria poética, sua especial compaixão à gente humilde com quem travou contato durante toda a sua vida. Para essas pessoas ele soube dedicar, além de espaços profícuos na produção ficcional, versos de grande sensibilidade e beleza.

"Quando ele nasceu, nascemos todos nós" (PESSOA, 1990, 345), dizia F. Pessoa acerca de António Nobre, que, segundo o autor de Mensagem, foi o primeiro a pôr em europeu este sentimento português das almas e das coisas... Nemésio, cremos, é o continuador dessa linhagem inaugurada pelo poeta de Só, pois, como este, despende também um olhar especial para sofrimentos de qualquer ordem, física ou moral, humana ou animal, afirma e preserva a identidade pátria e possui uma atenção ao específico das regiões, com suas festas tradicionais, além de retratar como poucos o imaginário do mundo marítimo e rural. É tema, portanto, para a poética nemesiana a evocação do mundo dos 
homens marçanos e de trabalho duro, da gente rude c'um saber só de experiências feito (CAMÕES, 1969, 380).

Ao lado de uma erudição ímpar, em Nemésio soma-se também uma veia popular profusa, rica, copiosa. Essas características são fruto, acreditamos, de seu espírito aberto para a beleza e para a arte onde quer que elas residam, seja em sua terra natal (as ilhas dos Açores), seja nos ambientes rurais ou cosmopolitas por onde passou em suas atividades acadêmicas na Europa e na América, especialmente no Brasil, país que amou e sobre o qual muito e bem retratou. Sobre a nossa pátria ele escreveu, entre outras obras: Sob os signos de agora: temas portugueses e brasileiros (1932), Portugal e Brasil no processo da história universal (1952), Poemas brasileiros (1952), O segredo de Ouro Preto e outros caminhos (1954), O campo de São Paulo (1954), Ode ao Rio (1965).

Nunca é demais lembrar que, além de retratar o Brasil em suas obras, a partir de 1958 Nemésio exerceu, como professor visitante, o magistério nas Universidades da Bahia, do Ceará e do Rio de Janeiro. Na última vez em que estivera no Brasil, faz um balanço de todos esses 20 anos de "visitação brasileira":

...Tantas vezes vai o cântaro à fonte, que racha - diz o ditado; e eu sou pote que vem à mãe-d'água brasílica pela sétima vez. Já é de durar! Fazme bem o rever — se bem me lembro... [...] Vinte anos de visitas ao Brasil têm-me ensinado muito. (NEMÉSIO, 1999, 276-278)

Resgatar, portanto, a obra desse escritor português constitui um trabalho de fomento de obras significativas, representando algumas delas marcos decisivos na história da literatura portuguesa do século XX. Conhecer e compreender a obra de Nemésio é uma atividade desenvolvida em nossa atividade de Pós-Graduação, sob a orientação da Profa. Dra. Maria Helena Nery Garcez, que ministra curso específico sobre o autor de Mau Tempo no Canal e também orientou e orienta alunos de mestrado e doutorado que estudam esse escritor. 


\section{$O$ resgate do humilde}

“Quem estima cantadores,/ Sabe o Padre-Nosso... reze-o!” (NEMÉSIO, 1989, 32). A prática desses "cantadores" e outras práticas estão na base da poética nemesiana. Daí a ocorrência em grande número de títulos de poemas registrados como "cantigas", "décimas" e "romances". Todas essas designações pertencem ao domínio da "literatura tradicional popular", oral ou escrita, e ocupam espaço privilegiado nas obras de Vitorino Nemésio, principalmente em Festa Redonda e Poemas Brasileiros.

Como me propus a especificar alguns casos desse resgate do humilde na poética nemesiana, começo destacando a presença de Genuína Baganha, criada da família de Nemésio e que tratou do poeta na infância: "A Genuína Baganha/ Foi servir pra nossa casa:/ Criou-me com melrinho/ Debaixo da sua asa!// Dava-me sopas de leite/ Cantando-me uma cantiga:/ 'O menino nã nas come?/ Nã nas acha na barriga!'” (NEMÉSIO, 1989, 165). Essa criada ficará para sempre na galeria dos homenageados por ilustres poetas.

$\mathrm{Na}$ "Décima do Pastor da Rapa", em momentos de grande intensidade expressiva, um "eu-outro", em primeira pessoa, assume a narrativa num discurso coloquial, com os regionalismos, com as pseudo-incorreções (por exemplo, "A gente, cá, semos proves”). Tudo flui o propósito de dar conta de um dia-a-dia que, na sua humildade, se valoriza por apontamentos líricos:

Pareço antão, nas canadas, Um ingraçado do intruido, Co a mascra do nevoeiro Que a gente chóma brabudo.

No mato só há mistério,

Trevinha, rapa e tamujo;

O Pico é um cão tinhoso

Nas barcas do Porco Sujo.

Mais lá vejo a flor do trevo

$\mathrm{E}$ as malhas da vaca-mestra;

Um chocalhinho de guexa...

Um raminho de giestra...” (NEMÉSIO, 1989, 110). 
A "Décima do Penitente" constitui um singelo texto sob a forma de "carta" à Mãe, ditada ao filho, num momento que precede a morte: "Minha Mãe, vou-te escrever!/ Meu filho, vou-te ditar!/ Meus vizinhos, vou morrer!/ Eu quero-me confessar!” (NEMÉSIO, 1989, 235). O "eu" moribundo vai recordando situações de infância bem representativas da realidade insular para, logo depois, imaginar e dramatizar o que o espera: "Num cemitério florido/ De boganguinho amarelo,/ Logo arriba do Verdoiço/ E do Jé Maria Belos" (NEMÉSIO, 1989, 239).

Algumas décimas reportam-se à exaltação de familiares ou amigos que ficaram para sempre na memória e no afeto do poeta: a "Décima a Um Parente Meu" é dedicada à lembrança do primo Chico Galhano, bom tocador de viola: “Tinhas coração do monte,/ Galhardia de cidade;/ Já me davas confiança/ Apesar da pouca idade.// E eu, vendo-te essa finura/ De ouvido encostado à toeira,/ Via nos teus olhos sérios/ O fundo da ilha Terceira" (NEMÉSIO, 1989, 191-92). Nos versos seguintes, é de se notar como o cotidiano, mesmo no seu prosaísmo, nas suas exclamações mais simples, torna-se sumo de uma poética expressividade: "Chico Galhano, que viola/ ao pé da tua se atreve?!/ Encheste a terra de ossos.../ Que a terra te seja leve!// E desculpa o desafino,/ Que Lá nos encontraremos/ E, nas violas dos anjos,/ Tocaremos... Tocaremos!" (NEMÉSIO, 1989, 197).

Já na "Décima da Música da Praia", em novo flagrante de um humilde sublime, notas de sensível lirismo captam em diminutivo a delicadeza de gestos destes versos:

\footnotetext{
Que o paj' da Croa é donzela, Poisa os olhinhos no chão, A mão na prega da saia, Compasso no coração.

Se lhe geme um saxofone Seu peito de rola acusa Um recato verdadeiro Debaixo da sua blusa...

Toca-lhe o passo picado, Canta-lhe a lume de archote, Borda de notas miudinhas A curva do seu decote.

Deita-lhe flores prateadas
} 
A bico de clarinete,

Pica-lhe o pé de silvinhas,

O peito de limonete... (NEMÉSIO, 1989, 152).

Mas não é somente o conjunto de poemas de Festa Redonda que nos propiciará exemplos do que queremos ressaltar aqui da poética nemesiana. Do livro $O$ Bicho Harmonioso recorremos ao poema "A Vaga Verde", que interliga discursos diferentes, que se versam numa linguagem simultaneamente melódica e coloquial. Esse texto pode ser considerado um romance popular de viagem que aglutina uma espécie de canção de amor. O tema, mais sugerido do que explicitado, participa assim da musicalidade própria do gênero, com retorno insistente do sintagma "vaga verde".

O sujeito lírico veste a pele do Capitão do Navio, personagem própria da narrativa oral (caso da conhecida "Nau Catrineta"): “[...] O Capitão não tem barbas/ (Isso era literatura): tem medo,/ Medo da vaga verde, de águas bravas;/ Disso fez a coragem e o segredo" (NEMÉSIO, 1989, 167).

A "vaga verde" representa aqui a tentadora sedução da aventura, encarnada pela mulher, que sugere o mito das sereias de Ulisses: "A vaga verde é um pouco mulher (para que o escondes?).../ Ora diz lá se não é seu cabelo esta água?/ [...]/ Então? Luta e briga com ela,/ Estala a cera ao seu destino selado,/ E, com sua água colérica,/ Lava a tua vela".

A viagem como percurso existencial do ser - ou do "Capitão do navio" - , desde a sua errância, toldada pela "névoa" do mar — ou da "Vaga Verde" —, até alcançar a quietação do "porto", versa-se numa tirada de longo fôlego, em paralelismo anafórico: "Para que um porto, enfim, enxugue essas velas molhadas;/ Para que descanses e aclares a névoa que te encobre e ofende; [ [...] Enfim, para que deixe de haver a vaga verde".

Observa-se nos fragmentos acima que, apesar de recorrer aos moldes populares da “canção-romance", esse poema alarga o seu sentido a uma dimensão metafísica da vida que transcende a aparente simplicidade dos ingredientes temático-formais. É fusão do humilde no sublime.

Os Poemas Brasileiros, em sua edição definitiva de 1972, estão estruturados em três divisões ou livros: "9 romances da Bahia", "Violão de morro" e "Ode ao Rio". Os "9 romances" na verdade compõem-se de 11 poemas, pois há um "Intróito" aos nove 
romances e, findos estes, há um poema sobre a cidade histórica de Outro Preto, intitulado "Elegia ao cemitério de Santa Efigênia de Outro Preto".

E é dessa "Elegia" que extraímos alguns belos e significativos exemplos do quanto a obra nemesiana pode revelar uma qualidade humana ímpar. Eis belas realizações poéticas de um olhar especial a uma raça deveras sofrida e esquecida:

Lembro-me tanto de tudo!

Cerra-se a vida no espelho

Que o destino humano tolda

Naquele cemiteriozinho

De Santa Efigênia núbia,

Todo flores e cruzes toscas.

Silêncios do sol mineiro

Guarda a lâmpada de prata

Na pobre igreja esquecida;

é tudo tão justo e humilde

À flor da terra mulata!

Ali jazem de Outro Preto

Pobres pepitas humanas" (NEMÉSIO, 1989, 486).

Esparramando seu olhar terno para os túmulos destituídos de grandes belezas arquitetônicas e enfeites suntuosos, assim o eu-lírico apresenta suas impressões desses jazigos:

Descansa em pás de Deus

(Com seu s) Rute Albana,

Ou seu túmulo é a lata de água?

Rute escondeu-se; descansa.

Cemiteriozinho negro

De Santa Efigênia núbia,

Fica no canto dos pássaros,

Nos letreiros de caixote,

Nas flores do mato queimado..."

[...]

Aqui dorme o sono eterno

O pequeno Elci. (NEMÉSIO, 1989, 487)

E, diante de todo esse quadro, irrompe a voz da enunciação em reflexão metafísica: “Seria/ Que eu tivesse a paz tão longe/ E, perto, a não merecia?” (NEMÉSIO, 1989, 487). 
Ainda no conjunto dos Poemas Brasileiros, no "Romance do Xangô", vale a pena destacar a figura central de Dàzinha, a iahorixá que dança o candomblé a que o espectador assiste fascinado. Esse romance estonteante, todo em metro redondilha maior, cujo ritmo vai num crescendo, num rodopio que reproduz a dança de Dàzinha, traz o ritual de iniciação a que a iahorixá se submeteu para poder dançar o cadomblé: "A sua lã de ovelhinha/ Nas mãos de Anísia deixou./ Seu cabelo vira arame/ De que tira os braceletes/ Para dançar a Xangô" (NEMÉSIO, 1989, 470). Chama-nos a atenção os diminutivos presentes nesses versos, demonstrando a ternura com que a voz da enunciação se refere a Dàzinha. Nesse romance, portanto, Nemésio presta sua homenagem à raça negra com quem ele tomou contato quando veio conhecer a Bahia, e também ao sagrado, que foi capaz de discernir em seus rituais.

A confissão religiosa de Nemésio não o faz despregar os olhos da realidade. Nela, ele tem um olhar especial para o humilde, cumprindo bem a lição que herdou de seu pai, que o "ensinou a amar o próximo e a ser justo" (NEMÉSIO, 1989, XXIX).

Nesse aspecto, é singular o poema "Natal Chique", de O Pão e a Culpa: "Valeu-me um príncipe esfarrapado/ A quem dão coroas no meio disto,/ Um moço doente, desanimado.../ Só esse pobre me pareceu Cristo (NEMÉSIO, 1989, 204).

Beleza e emotividade iguais também encontramos, no mesmo livro, nos poemas "A Morte do Pescador" e "Enterro Pobre", dos quais extraímos os fragmentos abaixo para servirem como sínteses da religiosidade transformadora de Nemésio:

\section{$[\ldots]$}

Era o Mestre Negrinho:

Agora, clareou.

Alguém desceu um fio de linho

À cova aberta, e lá o pescou. (NEMÉSIO, 1989, 213)

O sossego deste dia

São casas de rua morta

E um enterro ao entardecer,

Com o padre e a companhia

Que um pobrinho pode ter

Quando Deus lhe bate à porta. (NEMÉSIO, 1989, 214) 
Exemplos vários ainda poderiam ser apresentados aqui. Em todos veríamos a compaixão de Nemésio para a gente humilde de qualquer lugar, em toda situação.

Diante do que apresentamos e do que ainda com certeza muito poderia ser apresentado sobre o humilde sublime em Vitorino Nemésio, temos a certeza de que a súplica de António Nobre não ficou em vão: “Qu’é dos Pintores do meu país estranho,/ Onde estão eles que não vêm pintar?" (NOBRE, 2000, 193).

\section{Referências bibliográficas}

CAMÕES, Luís Vaz de. Os Lusíadas - IV, 94. Rio de Janeiro: Edições de Ouro, 1969.

GARCEZ, Maria Helena Nery. "A Bahia de Vitorino Nemésio". In: Estudos

Portugueses e Africanos, no 31, UNICAMP, Campinas, 1998, pp. 70-77.

- "De António Nobre a Vitorino Nemésio: linhagens". In: Voz

Lusíada. (Número Comemorativo), n. 17, Revista da Academia Lusíada de

Ciências, Letras e Artes, São Paulo. 2002, pp. 9-28.

NEMÉSIO, Vitorino. Obras Completas, vol. XVII, Conhecimento de Poesia. Jornal de

Vitorino Nemésio 4. Lisboa: Imprensa Nacional - Casa da Moeda, 1997.

. Obras Completas, vol. I e II: Poesia. Prefácio, organização e fixação de texto de

Fátima Freitas Morna. Lisboa: Imprensa Nacional - Casa da Moeda, 1989.

. Obras Completas, vol. XXI. Jornal do Observador. Jornal de Vitorino Nemésio 8.

2. ed. Lisboa, Imprensa Nacional - Casa da Moeda, 1999.

. “Carta-prefácio". in AAVV., Memorial da Muito Notável Vila da Praia da Vitória.

No Centenário da Acção de 11 de Agosto de 1829, Coimbra, Imprensa da Universidade, 1929, pp. XI-XVI. Citado em VITORINO NEMÉSIO - Obras Completas. Poesia vols. I e II, pág. XXIX. Lisboa, Imprensa Nacional-Casa da Moeda, 1989.

NOBRE, António. Poesia completa - 1867-1900. 1. ed. Lisboa: Publicações Dom Quixote, 2000.

PESSOA, Fernando. Obra em prosa. 1. ed. Rio de Janeiro: Nova Aguilar, 1990. 
Vv.Aa. Intelectuais portugueses e a cultura brasileira. Depoimentos e estudos. Organização Márcia Valéria Zamboni Gobbi, Maria Lúcia Outeiro Fernandes, Renata Soares Junqueira. 1. ed. São Paulo: Editora UNESP; Bauru, SP: EDUSC, 2002.

Vv.Aa. - Vitorino Nemésio vinte anos depois. Actas do Colóquio Internacional de Ponta Delgada. Lisboa: Edições Cosmos, 1998. 